\title{
Identity Gender Question sebagai Upaya Awal Pengenalan Gender pada Anak di Panti Asuhan Bunda Sumatera Selatan
}

\author{
Rosalita* \\ UIN Sunan Gunung Djati Bandung; rosalitaocak@gmail.com
}

\author{
*Penulis Korespondensi \\ Artikel Dikirim: 24 Agustus 2020; \\ Artikel Diterima: 25 Oktober 2020; \\ Artikel Dipublikasi: 16 Desember 2020.
}

\begin{abstract}
Abstrak: Wacana gender merupakan salah satu hal penting yang harus dipahami sejak dini karena berkaitan langsung dengan kehidupan sosial masyarakat dan perkembangan diri. Penelitian ini bertujuan untuk mengidentifikasi kemampuan anak-anak panti asuhan dalam mengenali gendernya lalu setelahnya memberikan pengenalan gender yang mudah dipahami dengan menggunakan pertanyaanpertanyaan yang menyelipkan isu gender dalam kehidupan sehari-hari, sehingga ketika ada kesalahpahaman atau bias gender yang terjadi, peneliti bisa meluruskan sesuai dengan teori yang ada. Adapun objek pada penelitian ini yaitu anak-anak Panti Asuhan Bunda Sumatera Selatan sebanyak 20 orang. Penelitian ini menggunakan metode deskriptif analisis yaitu mendeskripsikan atau memberi gambaran terhadap objek yang diteliti melalui data atau sampel yang telah terkumpul sebagaimana adanya. Teknik pengumpulan data yang digunakan adalah wawancara, observasi, dan dokumentasi. Adapun teknik analisis data penelitian ini menggunakan analisis data kualitatif dan kuantitatif. Hasil penelitian ini menunjukkan bahwa sekitar kurang lebih delapan puluh lima persen memahami tentang gender melalui pertanyaan yang diajukan. Maka, identity gender question sebagai langkah awal pengenalan gender bisa digunakan sebagai awal yang bagus agar anak-anak bisa memahami dengan mudah apa itu gender.
\end{abstract}

Kata Kunci: Anak-anak, Gender, Panti Asuhan

\begin{abstract}
Gender discourse is one of the important things that must be understood from an early age because it is directly related to social life and self-development. This study aims to identify the ability of the orphanage children to recognize their gender and then afterwards provide an easy-to-understand gender introduction using questions that include gender issues in everyday life, so that when there is a gender misunderstanding or bias that occurs, the researcher can straighten out according to the existing theory. The objects in this study were 20 children of the South Sumatra Mother Orphanage. This study uses a descriptive analysis method that describes or gives an overview of the object under study through data or samples that have been collected as they are. Data collection techniques used were interviews, observation, and documentation. The data analysis technique of this research uses qualitative and quantitative data analysis. The results of this study indicate that approximately eighty five percent understand about gender through the questions asked. So, the gender identity question as an initial step towards gender recognition can be used as a good starting point so that children can easily understand what gender is.
\end{abstract}

Keywords: Children, Identity Gender, Orphanage

\section{PENDAHULUAN}

Menurut WHO definisi anak adalah dihitung sejak seseorang di dalam kandungan sampai dengan usia 19 tahun. Menurut Undang-Undang Republik Indonesia nomor 23 tahun 2002 pasal 1 ayat 1 tentang perlindungan anak, anak adalah seseorang yang belum berusia 18 tahun, termasuk juga yang masih di dalam kandungan. Anak merupakan aset bangsa yang akan meneruskan perjuangan suatu bangsa, sehingga harus diperhatikan pertumbuhan dan perkembangannya (RI, 2010). 
Pengambilan sikap dalam pola asuh anak akan menentukan bagaimana seorang anak di masa yang akan datang, hingga wajib bagi orang tua untuk menyadari bahwa usia kanak-kanak adalah masa yang rentan dalam memberikan pola asuh. Pemberian pemahaman akan sesuatu juga pola asuh yang kurang tepat akan sangat mempengaruhi perkembangan anak di masa yang akan datang karena pada saat itu semua stimulus yang diberikan akan menjadi tombak awal seorang anak dalam membentuk konsep diri. Menurut Santrock (Hadianti, 2010) menyatakan bahwa aspek-aspek sosial kehidupan anak lebih cenderung pada identitas, relasi sosial, dan gender mereka.

Gender sendiri merupakan perbedaan antara laki-laki dan perempuan dalam peran, fungsi, hak, tanggung jawab, dan perilaku yang dibentuk oleh tata nilai sosial, budaya dan adat istiadat dari kelompok masyarakat yang dapat berubah menurut waktu serta kondisi setempat (Perempuan, 2001). Nasitotul Jannah juga menyebutkan bahwasannya gender pada hakikatnya adalah sebuah terma yang digunakan untuk membedakan peran antara laki-laki dan perempuan, hasil dari rekayasa manusia sebagai akibat pengaruh sosial budaya masyarakat yang tidak bermakna kodrati (Janah, 2017). Dilihat dari pengertian sebelumnya, maka gender berupaya untuk meningkatkan kepedulian masyarakat terhadap aspirasi, kepentingan dan peranan perempuan maupun laki-laki tanpa mengesampingkan harkat, kodrat, dan martabat dalam berbagai bidang.

Namun, mengingat masih melekatnya budaya patriarki dan juga adat ataupun kebiasaan yang sudah mengakar pada masyarakat Indonesia ditambah dengan kurangnya pemahaman atau sama sekali buta akan gender, membuat para pendididik, khususnya orang tua dirumah sebagai madrasah awal bagi anak akhirnya tidak tepat dalam memberikan pola asuh pada anak. Hingga pada dasarnya, setiap orang tua pasti memiliki refleks sendiri terhadap pembentukan gender anaknya. Misalkan anak laki-laki tidak boleh menangis dan harus kuat, sedangkan anak perempuan harus memiliki sisi yang manis dan kemayu. Hal-hal ini seperti terbentuk otomatis pada pola pikir orang tua. Padahal inilah yang dinamakan bias gender masih banyak orang tua yang masih bias terhadap apa itu gender dan akhirnya anak-anak pun tumbuh dalam aturan yang mengekang karena kekhawatiran orang tua akan tumbuh kembang anaknya yang tidak sesuai dengan jenis kelaminnya. Perilaku bias gender muncul karena ketidakadilan gender (Gender Inequality). Faktor ini diakibatkan karena sistem dan struktur sosial yang menempatkan kaum laki-laki dan perempuan pada posisi yang merugikan. Pandangan kaum feminis menegaskan bahwa munculnya konsep ini karena konsep gender dan konsep dimaknai sama oleh sistem dan struktur itu sendiri. Berbagai bentuk ketidakadilan gender tersebut adalah: marginalisasi, subordinasi, stereotipe, kekerasan (violence) dan beban kerja lebih panjang dan lebih banyak double burden). Sama seperti yang diungkapkan oleh Hyde (Santrock, 2007) bahwa: "selama berpuluh-puluh tahun masyarakat memiliki bias gender yang kuat, pandangan yang kaku mengenai kemampuan laki-laki dan perempuan yang akhirnya mencegah individu mengejar minat untuk mencapai potensi mereka."

Panti asuhan berperan sebagai pengganti keluarga untuk memenuhi kebutuhan anak dalam proses perkembangannya. Anak panti asuhan hidup dalam berbagai dimensi sosial dan dituntut harus bisa berbaur dan bersosialisasi langsung dengan seluruh penghuni panti. Interaksi ini menimbulkan penilaian dan pandangan dari sesama teman karena anak-anak berasal dari status dan latar belakang yang berbeda, dan mengakibatkan adanya perbedaan watak dan karakter pada penghuni panti asuhan (Afandi, 2019). Maka tentu saja ini akan mempengaruhi bagaimana pola pemikiran mereka, dan hanya 
harus terus mengikuti arus dimana mereka secara tidak langsung terpaksa mengikuti apa yang terjadi tanpa diberi pemahaman apakah itu salah ataukah benar.

Adapun Jenis metode penelitian yang dipilih adalah deskriptif analisis, adapun pengertian dari metode deskriptif analisis menurut (Sugiyono, 2010) adalah suatu metode yang berfungsi untuk mendeskripsikan atau memberi gambaran terhadap objek yang diteliti melalui data atau sampel yang telah terkumpul sebagaimana adanya tanpa melakukan analisis dan membuat kesimpulan yang berlaku untuk umum.

Lokasi penelitian ini dilakukan pada Panti Asuhan Bunda di Kabupaten Banyuasin, Sumatera Selatan. Sesuai dengan judul, penelitian ini dilakukan untuk mengetahui bagimana tanggapan anak-anak panti asuhan yang sebelumnya buta sama sekali masalah gender melalui identity gender question, yang selanjutnya diberikan stimulus-stimulus awal pengenalan gender yang sudah disesuaikan dengan poinpoin gender question agar kedepannya mereka memahami dengan baik apa itu gender dengan mudah dimengerti.

Teknik pengumpulan data dalam penelitian ini yaitu: (1) Teknik wawancara tidak terstruktur adalah cara pengambilan data penelitian dengan cara peneliti hanya menentukan fokus masalah saja dan tidak memberikan alternatif jawaban yang harus dipilih informan (Musfiqon, 2012). Dengan kata lain wawancara ini seperti percakapan dua arah dan saling menanggapi antara pewawancara dan informan. Wawancara dilakukan secara bertatap muka langsung dengan kepala Panti Asuhan Bunda sebagai orang yang menjadi pengawas dan juga pendidik langsung bagi anak-anak panti asuhan. Adapun informannya adalah Ibu Rani yang sudah menjadi kepala pengurus di Panti Asuhan Bunda semenjak pertama kali panti asuhan dibangun pada tahun 2014. (2) Teknik observasi yaitu dengan melihat langsung perilaku anak-anak panti asuhan selama empat kali dalam kurun waktu dua minggu. Kemudian dilanjutkan dengan mengajukan pertanyaan seputar identity gender question yang telah peneliti susun berdasarkan permasalahan gender yang telah pada kehidupan sehari-hari sesuai dengan teori yang ada pada anak-anak panti asuhan, lantas setelahnya peneliti bisa memberikan stimulus-stimulus pengenalan awal tentang gender. Pengambilan sample pada penelitian ini dengan menggunakan metode simple random sampling, yaitu pengambilan sample secara acak tanpa menentukan umur dan jenis kelamin. Terdapat dua puluh anak Panti Asuhan Bunda dengan umur yang beragam, dari kisaran empat tahun yang paling kecil hingga paling besar adalah enam belas tahun sebagai responden identity gender question. Semua anak adalah penghuni tetap Panti Asuhan Bunda dengan latar belakang keluarga yang berbeda-beda. Ada yang memang sudah tidak memiliki orang tua sama sekali, dan ada juga yang masih memiliki orang tua, tetapi karena alasan tidak mampu, maka anaknya pun dititipkan di panti asuhan ini. (3) Teknik dokumentasi berupa pengumpulan data-data kegiatan anak-anak selama di panti asuhan untuk dianalisis dan foto-foto saat pembelajaran. Juga arsip-arsip dokumen yang berisi tentang teoriteori yang berkaitan langsung dengan penelitian sebagai landasan acuan.

\section{Pembahasan}

\subsection{Memahami Gender dan Isu Gender}

Secara umum, pengertian Gender adalah perbedaan yang tampak antara laki-laki dan perempuan apabila dilihat dari nilai dan tingkah laku. Dalam Women Studies Ensiklopedia yang dijelaskan oleh Umar 
bahwa Gender adalah suatu konsep kultural, berupaya membuat perbedaan (distinction) dalam hal peran, perilaku, mentalitas, dan karakteristik emosional antara laki-laki dan perempuan yang berkembang dalam masyarakat (Putri, 2019).

Sebagaimana yang dikutip oleh Alan Sigit Fibrianto (2016:12-13) dari Heddy Shri Ahimsha Putra (2000) menegasakan bahwa istilah gender dapat dibedakan ke dalam beberapa pengertian berikut ini: gender sebagai suatu istilah asing dengan makna tertentu, gender sebagai suatu fenomena sosial budaya, gender sebagai suatu kesadaran sosial, gender sebagai suatu persoalan sosial budaya, gender sebagai sebuah konsep untuk analisis, Gender sebagai sebuah perspektif untuk memandang kenyataan (Fibrianto, 2016; Putra, 2000).

Jadi, bisa dikatakan bahwasannya gender terbentuk sebagaimana kebiasaan atau tradisi yang terjadi di suatu tempat. dengan demikian gender sebagai suatu konsep merupakan hasil pemikiran manusia atau rekayasa manusia, dibentuk oleh masyarakat sehingga bersifat dinamis dapat berbeda karena perbedaan adat istiadat, budaya, agama, sitem nilai dari bangsa, masyarakat, dan suku bangsa tertentu. Selain itu gender dapat berubah karena perjalanan sejarah, perubahan politik, ekonomi, sosial dan budaya, atau karena kemajuan pembangunan. Dengan demikian gender tidak bersifat universal dan tidak berlaku secara umum, akan tetapi bersifat situasional masyarakatnya.

Berbicara tentang gender, maka tidak akan jauh juga untuk menyangkut tentang patriarki. Menurut Alfian Rokhmansyah di bukunya yang berjudul Pengantar Gender dan Feminisme, patriarki berasal dari kata patriarkat, berarti struktur yang menempatkan peran laki-laki sebagai penguasa tunggal, sentral, dan segala-galanya (Rokhmansyah, 2016). Sistem patriarki yang mendominasi kebudayaan masyarakat menyebabkan adanya kesenjangan dan ketidakadilan gender yang mempengaruhi hingga ke berbagai aspek kegiatan manusia. Laki-laki memiliki peran sebagai kontrol utama di dalam masyarakat, sedangkan perempuan hanya memiliki sedikit pengaruh atau bisa dikatakan tidak memiliki hak pada wilayah-wilayah umum dalam masyarakat, baik secara ekonomi, sosial, politik, dan psikologi, bahkan termasuk di dalamnya institusi pernikahan.

Perbedaan gender terkadang dapat menimbulkan suatu ketidakadilan terhadap kaum laki-laki dan terutama kaum perempuan. Ketidakadilan gender dapat termanifestasi dalam berbagai bentuk ketidakadilan. Mansour Fakih menyebutkan terdapat lima ketidakadikan yang terjadi antara laki-laki dan perempuan yaitu, (1) marjinalisasi, (2) subrodinasi, (3) stereotype, (4) beban ganda, dan (5) kekerasan (Fakih, 1996). Mengutip hal tersebut Agus Afandy (2019:5-6) menjabarkan tentang ketidakadilan gender yang melahirkan isu-isu gender terangkum sebagai berikut (Afandi, 2019):

1. Marjinalisasi Perempuan

Marginalisasi perempuan adalah salah satu bentuk ketidakadilan terhadap gender. Disadari ataupun tidak disadari di lingkungan sekitar kita sering terjadi marginalisasi perempuan (penyingkiran/ pemiskinan). sebagai contohnya yaitu internsifikasi pertanian bagian dari program pembangunan hanya memfokuskan pada laki-laki yang mengakibatkan tersingkirnya pekerja perempuan dan jatuh miskin. Perempuan dipinggirkan dari berbagai jenis kegiatan pertanian dan industri yang lebih memerlukan keterampilan yang biasanya lebih banyak dimiliki laki-laki, dan perkembangan teknologi telah menyebabkan apa yang semula dikerjakan secara manual oleh perempuan diambil alih oleh mesin yang umumnya dikerjakan oleh tenaga laki-laki. Dengan hal ini 
banyak sekali kaum pria yang beranggapan bahwa perempuan hanya mempunyai tugas di sekitar rumah saja.

\section{Subordinasi}

Subordinasi adalah salah satu bentuk keadilan dengan keyakinan bahwa salah satu jenis kelamin dianggap lebih penting atau lebih utama dibandingkan jenis kelamin lainnya. Sudah sejak dahulu terdapat pandangan yang menempatkan kedudukan dan peran perempuan yang lebih rendah dari lakilaki. Salah satu contohnya yaitu perempuan di anggap makhluk yang lemah, sehingga sering sekali kaum adam bersikap seolah - olah berkuasa (wanita tidak mampu mengalahkan kehebatan laki-laki). Kadang kala kaum pria beranggapan bahwa ruang lingkup pekerjaan kaum wanita hanyalah disekitar rumah. Dengan pandangan seperti itu, maka sama halnya dengan tidak memberikan kaum perempuan untuk mengapresiasikan pikirannya di luar rumah.

\section{Pandangan Stereotype}

Diskriminasi terhadap perempuan dan berbagai ketidakadilan yang merugikan perempuan salah satunya karena pandangan stereotype terhadap perempuan. Stereotype dimaksud adalah citra baku tentang individu atau kelompok yang tidak sesuai dengan kenyataan empiris yang ada. Pelabelan negatif secara umum selalu melahirkan ketidakadilan. Misalnya pandangan terhadap perempuan yang tugas dan fungsinya hanya melaksanakan pekerjaan yang berkaitan dengan pekerjaan domistik atau kerumahtanggaan. Hal ini tidak hanya terjadi dalam lingkup rumah tangga tetapi juga terjadi di tempat kerja dan masyaraklat, bahkan di tingkat pemerintah dan negara.

Apabila seorang laki-laki marah, ia dianggap tegas, tetapi bila perempuan marah atau tersinggung dianggap emosional dan tidak dapat menahan diri. Standar nilai terhadap perilaku perempuan dan lakilaki berbeda, namun standar nilai tersebut banyak menghakimi dan merugikan perempuan. Label kaum perempuan sebagai "ibu rumah tangga" merugikan, jika hendak aktif dalam "kegiatan laki-laki" seperti berpolitik, bisnis atau birokrat. Sementara label laki-laki sebagai pencari nafkah utama, (breadwinner) mengakibatkan apa saja yang dihasilkan oleh perempuan dianggap sebagai sambilan atau tambahan dan cenderung tidak diperhitungkan.

\section{Beban Ganda}

Dalam berbagai observasi, perempuan dalam rumah tangga diketahui mempunyai pekerjaan rumah tangga melebihi laki-laki dengan nilai 90\%, sehingga bagi perempuan yang bekerja di luar rumah, setelah bekerja diluar mempunyai beban ganda karena harus pula berperan dominan mengerjakan banyak pekerjaan di rumah. Hal ini merupakan diskriminasi dan ketidakadilan gender, karena harus melakukan pekerjaan diluar dan didalam rumah lebih banyak dibanding laki-laki. Selain itu juga terjadi banyak ketimpangan dan pembedaan perlakuan perempuan di kalangan public.

\section{Kekerasan}

Kekerasan merupakan bentuk kekerasan baik fisik maupun non fisik yang dilakukan oleh salah satu jenis kelamin, keluarga, masyarakat, negara kepada jenis kelamin lainya. Kekerasan semata-mata ada bermula dari pembedaan antara feminim dan maskulin. Pembedaan tersebut telah memicu kekerasan terjadi. Contohnya, pemerkosaan, kekerasan seksual, pelecehan seksual, pemukulan, penghinaan, eksplotasi seks pada perempuan dan lain-lain.

Kelima isu gender itu merupakan masalah utama yang akhirnya menjadi wacara ketidakadilan dan 
perbedaan gender yang di Indonesia sudah menjadi sebuah konstruksi soial yang sulit sekali diubah. Maka pentingnya pengenalan gender sejak dini terhadap anak-anak harus dilakukan sebagai upaya mengurangi isu-isu gender yang terjadi di Indonesia.

\subsection{Profil Panti Asuhan Bunda}

Perkembangan panti asuhan di Indonesia saat ini cukup dinamis sebagai salah satu upaya untuk memperbaiki masa depan anak. Panti asuhan merupakan suatu lembaga yang sangat populer untuk membentuk perkembangan anak-anak yang tidak memiliki keluarga ataupun yang tidak tinggal bersama dengan keluarga agar potensi dan kapasitas belajarnya pulih kembali dan dapat berkembang dengan wajar (RI, 2010). Anak - anak panti asuhan diasuh oleh pengasuh sebagai pengganti orangtua, menjaga dan memberikan bimbingan kepada anak agar anak menjadi manusia dewasa yang berguna dan bertanggung jawab atas dirinya dan terhadap masyarakat di kemudian hari (Santoso, 2015).

Penelitian ini dilaksanakan di Panti Asuhan Bunda Banyuasin, Sumatera Selatan. Panti asuhan ini dibangun pada tahun 2014 dan di inisiasi pertama kali oleh Bunda Rini. Pada awal pembangunan, panti ini hanya memiliki satu rumah untuk menampung sepuluh anak yang memang datang dengan sendirinya ke panti tersebut dengan berbagai alasan, yaitu: (1) Ada yang orang tuanya tidak sanggup untuk menghidupi anaknya, maka anaknya dititipkan di panti asuhan, walaupun pada akhirnya tidak pernah dijenguk lagi oleh orang tuanya. (2) Anak hasil hubungan terlarang dan biasanya dari bayi sudah dititipkan di panti asuhan ini. (3) Anak yang tidak memiliki orang tua sama sekali dan akhirnya memilih untuk tinggal di panti asuhan ini.

Sekarang Panti Asuhan Bunda sudah memiliki tiga rumah, rumah yang pertama kali dibangun dijadikan sebagai kantor dan juga rumah oleh pengurus-pengurus panti dengan kisaran lima pengurus termasuk Ibu Rini. Bahkan ada salah seorang pengurus panti yang merupakan orang datangan dari Jawa Tengah yang berniat awal mencari pekerjaan, namun sejak tahun 2018 sampai seka rang belum mendapatkan pekerjaan, pengurus yang bernama Bu Ratni akhirnya memilih tinggal di panti asuhan bersama anaknya yang ia akui memiliki IQ rendah - tidak mudah menangkap sesuatu dengan cepat. Dua rumah selanjutnya merupakan tempat tinggal anak-anak panti asuhan yang masih terbuat dari dinding kayu dan lantai semen, berbeda dengan rumah ibu-ibu pengurus panti yang sudah terbuat dari beton. Ketika ditanya alasannya mengapa rumah untuk tinggal anak-anak tidak dibeton, Ibu Rani mengatakan bahwa biaya yang ada tidak cukup untuk memperbaiki rumah tinggal anak panti. Terakhir, panti asuhan ini sudah memiliki masjid sebagai tempat anak-anak belajar mengaji, beribadah, dan melakukan berbagai kegiatan.

Setelah peneliti melakukan pengamatan beberapa kali ke panti asuhan ini dan juga ikut andil dalam mengajar mengaji, anak-anak terlihat sangat ceria sekali, wajah-wajah mereka pun seperti tidak ada beban. Ketika diajarkan berbagai materi mengaji pun mereka menanggapinya dengan antusias. Namun pada satu kali kesempatan, saat peneliti mengajar, hanya ada beberapa anak panti asuhan yang ikut mengaji, saat ditanyakan alasannya mengapa yang lain tidak terlihat, mereka menjawab bahwa ada yang pulang kampung. Maka, setelah ditarik kesimpulannya adalah masih banyak orang tua-orang tua anak-anak yang merasa tidak mampu dan memilih menyerah untuk mendidik anaknya langsung. Padahal sudah jelas bahwa pendidikan yang diberikan oleh orang tua pertama kali lah yang lebih 
melekat pada emosional anak-anak, karena, bisa saja ada anak-anak yang berpikir dan merasa bahwa mereka berada di panti asuhan karena tidak diinginkan kelahirannya sehingga bisa saja menjadi beban moral bagi mereka dan berujung pada rusaknya pembentukan konsep diri mereka di masa yang akan datang.

\subsection{Penerapan Identity Gender Question di Panti Asuhan Bunda}

Seperti yang telah tertuang pada judul, bahwasannya penelitian ini menggunakan model question dimana akan diberikan beberapa pertanyaan terkait gender dan akan langsung dikaitkan pada anakanak panti asuhan yang memang sebelumnya sama sekali tidak memiliki pengetahuan tentang apa itu gender. Adapun pertanyaan-pertanyaan tersebut akan dikelompokkan sesuai dengan empat isu gender yang sudah disebutkan pada sub bab sebelumnya, yaitu (1) Marjinalisasi perempuan, (2) Subordinasi, (3) Stereotip, (4) Beban ganda, dan (5) Kekerasan.

Karena umur anak-anak yang menjadi responden berbeda-beda, maka pendapat mereka pun tentu berbeda sesuai dengan apa yang mereka alami dan rasakan di realita kehidupan nyata, sehingga dari sana mereka mungkin sudah tanpa sadar menyimpulkan apa itu arti kesetaraan dan keadilan gender tanpa mereka ketahui bahwa mereka sudah memahaminya atau belum.

Selanjutnya, yang menjadi catatan besar, setelah peneliti melakukan wawancara bersama Ibu Rini, beliau mengatakan bahwa sebagian besar anak-anak panti asuhan disini memiliki keterbelakangan IQ yang membuat mereka sulit sekali untuk menangkap sesuatu dengan cepat. Contohnya, ada seorang anak yang bernama Febri berumur enam belas tahun memiliki masalah disabilitas yaitu kesulitan dalam berbicara juga keterbelakangan mental dan satu lagi ada seorang anak perempuan berumur empat belas tahun yang memiliki panggilan akrab Gades sangat sulit berkomunikasi, padahal dilihat dari penampilan ia seperti tidak memiliki permasalahan apapun.

Maka dari itu, tujuan dari penelitian ini adalah memberikan pertanyaan-pertanyaan yang sekiranya mudah ditangkap dan dipahami oleh anak-anak panti asuhan karena berkaitan dengan kehidupan mereka sehari-hari. Dengan menggunakan metode simple random sampling, peneliti mengambil sample anak sebanyak 20 orang dari jumlah 30 orang dengan alasan beberapa dari mereka ada yang masih berumur dua tahun dan tiga tahun yang tentu saja belum mengerti apa-apa, dan sisanya lagi memilih enggan keluar kamar, walaupun sudah diajak untuk berkumpul, jadi kisaran yang peneliti ambil adalah anak-anak yang berada pada umur 4-16 tahun.

Pada pertanyaan-pertanyaan tentang identity gender question ini juga tidak hanya memfokuskan pada permasalahan yang terjadi pada perempuan juga, tetapi juga bagaimana menganggapi isu-isu gender yang melekat pada laki-laki seperti apakah laki-laki juga boleh bersolek sebagaimana perempuan? Adapun pengelompokan pertanyaan dan juga kaitannya dengan empat isu gender yang telah dijabarkan tadi dikelompokkan dalam tabel berikut.

Tabel 1. Pengelompokan identity gender question dan isu gender

\begin{tabular}{cccccc}
\hline \multirow{2}{*}{ Isu Gender } & & & \multicolumn{2}{c}{ Jawaban } & \multicolumn{2}{c}{ Tdentity gender Question } & Boleh & Tidak boleh \\
\hline Marjinalisasi & 1. & Boleh/tidak perempuan pulang larut malam? & 5 anak & 15 anak \\
\hline & 2. & Boleh/tidak boleh perempuan bersekolah? & 20 anak & 0 anak \\
\hline
\end{tabular}




\begin{tabular}{|c|c|c|c|}
\hline \multirow[b]{2}{*}{ Isu Gender } & \multirow[b]{2}{*}{ Identity gender Question } & \multicolumn{2}{|c|}{ Jawaban } \\
\hline & & Boleh & Tidak boleh \\
\hline \multirow[t]{3}{*}{ Subordinasi } & $\begin{array}{l}\text { 1. Boleh tidak perempuan menjadi pemimpin seperti } \\
\text { presiden, bupati, dan sebagainya? }\end{array}$ & 19 anak & 1 anak \\
\hline & 2. Boleh/tidak boleh perempuan menjadi tentara? & 17 anak & 3 anak \\
\hline & $\begin{array}{l}\text { 3. Boleh/tidak boleh perempuan bekerja di pabrik } \\
\text { sebagai buruh angkut barang misalnya? }\end{array}$ & 12 anak & 8 anak \\
\hline \multirow[t]{3}{*}{ Stereotip gender } & $\begin{array}{l}\text { 1. Boleh tidak laki-laki menggunakan peralatan make } \\
\text { up seperti bedak dan lipstick? }\end{array}$ & 4 anak & 16 anak \\
\hline & $\begin{array}{l}\text { 2. Boleh tidak laki-laki menangis jika dia memang } \\
\text { merasa tersakiti? }\end{array}$ & 8 anak & 12 anak \\
\hline & $\begin{array}{l}\text { 3. Boleh tidak laki-laki bermain boneka dan } \\
\text { perempuan bermain mobil-mobilan? }\end{array}$ & 5 anak & 15 anak \\
\hline \multirow[t]{2}{*}{ Beban Ganda } & $\begin{array}{l}\text { 1. Boleh tidak perempuan bekerja kantoran } \\
\text { sedangkan laki-laki di rumah memasak dan } \\
\text { sebagainya? }\end{array}$ & 20 anak & 0 anak \\
\hline & $\begin{array}{l}\text { 2. Boleh tidak laki-laki memasak, membersihkan } \\
\text { rumah, menyapu, mengepel, dan sebagainya? }\end{array}$ & 20 anak & 0 anak \\
\hline Kekerasan & 1. Boleh/tidak boleh perempuan memukul laki-laki? & 0 anak & 20 anak \\
\hline
\end{tabular}

Pertanyaan-pertanyaan di atas sebenarnya memiliki inti yang sama dimana kita akan disuruh berpikir bahwasannya dalam kehidupan sehari-hari secara tidak sadar kita melakukan hal yang sudah benar atau malah sebaliknya, pun pemikiran kita tentang gender terkadang terlalu mengikuti tradisi atau kebisaaan sehingga terkadang malah terjadi ketidakadilan gender didalamnya.

Berikut merupakan rangkuman dari observasi langsung yang dilakukan pada anak-anak Panti Asuhan Bunda yang masih buta tentang gender. Beberapa pertanyaan ada yang sama sekali tidak diberi tanggapan dan hanya diberi jawaban boleh atau tidak boleh saja, karena mereka sulit untuk merangkai kata-katanya dan juga lebih memilih diam. Juga ada beberapa pertanyaan yang tidak mereka setujui boleh atau tidaknya, mereka akan memberikan respon gelengan kepala, alis yang terangkat satu, kernyitan dahi, atau juga berbicara dengan teman sebelahnya untuk menanyakan kenapa hal itu boleh/tidak boleh.

Pertama, pertanyaan tentang marjinalisasi yang berarti pembatasan hal-hal yang dilakukan perempuan. Dalam hal ini diajukan dua pertanyaan. (1) Pertanyaan pertama adalah boleh atau tidakkah perempuan pulang larut malam. Lima orang dari dua puluh anak menjawab boleh sedangkan sisanya menjawab tidak boleh. Salah satu dari lima anak tersebut langsung mengernyitkan dahinya karena merasa pulang malam merupakan hal yang tidak baik bagi perempuan, lantas ia langsung menanyakan mengapa pulang malam bagi perempuan itu dianggap boleh.

Pada kehidupan nyata, banyak orang tua beranggapan bahwa perempuan tidak boleh keluar malam dan tidak memberikan peringatan serupa pula pada laki-laki dikarenakan takutnya terjadi tindakan pelecehan karena di malam hari itu biasanya sepi, sehingga jika perempuan melanggar orang tua akan memarahi anaknya tersebut. Tentu hal ini harus diluruskan kembali kepada anak-anak, bahwasannya 
tidak ada pembatasan untuk perempuan atau laki-laki keluar malam hari, yang terpenting bagi anak perempuan harus ada yang menjaga selama keluar rumah. Jika yang ditakutkan adalah jika anak perempuan akan lebih mudah dilecehkan, maka jika kita balikan fakta anak laki-laki tidak boleh keluar rumah pada malam hari dan perempuan boleh, apakah ada perempuan yang dilecehkan? Tentu tidak ada. (2) Pertanyaan kedua tentang perempuan boleh atau tidak boleh sekolah. Dua puluh anak menyatakan boleh yang artinya semua setuju karena tentu di jaman sekarang perempuan maupun lakilaki dituntut untuk bisa hidup cerdas agar bisa melalui perkembangan zaman.

Kedua, pertanyaan tentang subordinasi yang berarti pengelompokan-pengelompokan yang tidak adil, seperti memandang jenis kelamin laki-laki atau perempuan. (1) Pertanyaan pertama tentang boleh tidak perempuan menjadi pemimpin, sembilan belas anak menjawab boleh dan satu orang menjawab tidak boleh. Salah satu dari sembilan belas anak mengatakan bahwasannya boleh saja perempuan menjadi pemimpin asal ia benar-benar memilik kemampuan dalam bidang tersebut, ini menunjukkan bahwa mereka sudah memiliki setidaknya bayangan tentang gender yang mulai dinamis. Satu orang yang menyatakan tidak boleh mengatakan bahwa sudah kodrat laki-laki menjadi pemimpin. Tentu pemikiran ini harus dibenahi karena setiap orang bisa menjadi pemimpin selagi ia mampu untuk menjalankannya. (2) Pertanyaan kedua boleh tidak perempuan menjadi tentara. Tujuh belas anak menyatakan boleh dan tiga lagi menyatakan tidak boleh karena beranggapan perempuan tidak sesuai dengan pekerjaan yang melibatkan fisik yang terlalu keras. Ini tentu saja anggapan yang salah, karena setiap orang bisa menjadi apa saja selagi ia mampu melakukannya, dan ini merupakan persepektif ketidakadilan gender tentang sisi maskulin dan feminin. (3) Pertanyaan ketiga boleh atau tidak perempuan menjadi buruh angkut barang di sebuah pabrik. Dua belas anak menyatakan boleh dan sisanya delapan orang menyatakan tidak boleh, salah satu dari mereka beranggapan bahwa sesuatu yang sulit dilakukan oleh laki-laki karena sudah menjadi kodratnya laki-laki melindungi wanita. Padahal lagi-lagi ini menjadi hal yang boleh saja karena kembali lagi pada mampukah seseorang wanita itu untuk melakukan hal tersebut atau tidak.

Ketiga, stereotip gender atau pelabelan yang merugikan salah satu pihak. (1) Pertanyaan pertama dalam sudut pandang bagaimana menanggapi laki-laki yang bersolek layaknya perempuan. Empat orang anak menyatakan boleh dan enam belas anak menyatakan tidak boleh. Yang menyatakan tidak boleh ada yang berceletuk bahwa jika laki-laki bersolek itu terlihat seperti banci. Tentu saja ini membutuhkan pelurusan, karena sah-sah saja bagi laki-laki yang bersolek atau berdandan, tapi tentu saja sesuai kebutuhan, misal agar tampilan terlihat rapi dan tidak acak-acakan maka tentu saja boleh dilakukan. (2) Pertanyaan kedua boleh tidak laki-laki menangis layaknya perempuan jika benar-benar tersakiti. Delapan anak menyatakan boleh dan dua belas anak menyatakan tidak boleh. Konstruksi pemikiran ini memang sudah tidak asing lagi mengatakan bahwa lelaki adalah manusia yang kuat dan tidak boleh menangis jika kesulitan. Padahal tentu saja ini pemahaman yang salah, setiap orang punya batas kemampuannya sendiri begitu pula dengan laki-laki, jadi boleh saja bagi laki-laki untuk mengeluarkan kesedihannya jika dirasa bisa melegakan perasaan. (3) Pertanyaan ketiga tentang laki-laki yang bermain boneka dan perempuan yang bermain mobil, lima anak menyatakn boleh dan lima belas lainnya menyatakan tidak boleh dengan kebanyakan alasan dari mereka hal tersebut tidak cocok bagi jenis kelamin mereka. Padahal pemikiran ini tentu saja salah, karena permainan anak sebetulnya sama saja, 
hanya memang ada beberapa permainan yang dibedakan berdasarkan gender. Penelitian menemukan bahwa memisahkan mainan berdasarkan jenis kelamin bisa memengaruhi perkembangan anak dalam jangka panjang. Dari penemuan tersebut banyak produsen mainan di Amerika dan Inggris menghentikan dalam mengkategorikan mainan berdasarkan jenis kelamin lewat kampanye yang diserukan "Mainan hanyalah mainan"(Nadiyah, 2019).

Keempat, berkaitan dengan beban ganda yang melibatkan sektor publik dan domestik, biasanya orang-orang beranggapan laki-laki yang cocok bekerja di sektor publik dan perempuan di ranah domestik yaitu misalnya di rumah saja. Pertanyaan yang diajukan sebenarnya mengandung makna yang sama dan jawaban mereka antara pertanyaan satu dan dua pun menjawab boleh yang artinya boleh adanya campur aduk pekerjaan laki-laki dan perempuan dalam sektor publik dan domestik, misal seperti laki-laki memasak dan perempuan bekerja di kantor. Tidak ada salahnya bagi laki-laki memasak, mengasuh dan menjaga anak di rumah, karena itu merupakan tanggung jawab bukan hanya tanggung jawab seorang ibu.

Kelima, berkaitan dengan kekerasan atau violence. Seringkali di dengar bahwasannya yang menjadi korban kekerasan adalah perempuan karena adanya sifat patriarki atau superior yang akhirnya menjadi konstruk sosial di masyarakat dan akhirnya dianggap menjadi hal yang biasa. Setelah ditanyakan pada anak-anak panti asuhan tentang kekerasan terhadap perempuan, tentu saja mereka menjawab dengan jelas bahwa itu tidak boleh. Namun bagaimana jika perempuan yang melakukan kekerasan terhadap laki-laki. Terkadang kita juga melupakan bahwasannya tidak hanya laki-laki yang bisa melakukan kekerasan namun juga perempuan. Tapi tentu saja, segala sesuatu yang bersifat kekerasan yang terjadi diantara laki-laki dan perempuan tidak harusnya terjadi.

Penjelasan diatas merupakan hasil yang berhasil dirangkum dari pengenalan gender yang peneliti lakukan terhadap anak panti asuhan. Semua menjawab dan tidak ada yang abstain karena kelebihan dari model penelitian ini adalah ditanyakan dengan konsep realita dan anak-anak yang berumur empat tahun pun bisa menjawab.

\section{Kesimpulan}

Dari hasil penelitian didapatkan sekitar 72 persen anak-anak sudah memahami apa itu wacana gender dar pemahaman mereka pada realita yang ada. Setelah diberikan pertanyaan tersebut, tanggapan yang semula keliru mereka pahami, berangsur-angsur dimengerti oleh mereka. Seorang anak panti asuhan yang bernama Rama berumur enam belas tahun berani memberi kesimpulan bahwasannya tentang gender, 'bahwasannya setiap orang itu sama, yang membedakan hanya jenis kelamin mereka dan kemampuan mereka terhadap melakukan sesuatu'.

Gender pada hakikatnya adalah sebuah terma yang digunakan untuk membedakan peran antara laki-laki dan perempuan, hasil dari rekayasa manusia sebagai akibat pengaruh sosial budaya masyarakat yang tidak bermakna kodrati (Janah, 2017). Di dalam Women's Studies Encyclopedia disebutkan gender adalah suatu konsep kultural yang berupaya membuat perbedaan (distinction) dalam hal peran, prilaku, mentalitas dan karakteristik emosional antara laki-laki dan perempuan yang berkembang di dalam masyarakat tanpa konotasi-konotasi yang sepenuhnya bersifat biologis. 
Pemahaman tentang gender berkaitan keadilan dan ketidakadilan gender itu sangat harus diajarkan sejak dini kepada anak-anak, karena ini berkaitan langsung dengan bagimana mereka membentuk konsep diri yang akan dibawa pada kehidupan bermasyarakat nanti. Jika hal ini tidak dilakukan, maka akan ditakutkan munculnya sifat superior dimana seseorang merasa bahwa dirinya berada diatas segalanya, dan biasanya sifat ini terjadi pada laki-laki karena di Indonesia budaya dan tradisi patriarki secara tidak langsung masih melekat kuat di masyarakatnya. Sebaliknya bagi perempuan jika tidak diberikan pemahaman tentang gender yang benar maka ditakutkan akan timbulnya perasaan dinomorduakan, tidak percaya diri, dan juga merasa ia tidak mampu melakukan apapun, dan akan berujung dimana ia akhirnya selalu menerima di dominasi dan terjadinya tindak kekerasan tanpa mampu untuk melawan.

Perkembangan identitas dan peran gender anak pada semua rentang usia masih dalam keadaan wajar. Secara kognitif, anak-anak telah mengetahui identitas gendernya. Anak-anak pun beraktivitas sesuai dengan peran gender yang dimiliki. Namun, memang terdapat sejumlah kecil anak-anak yang menunjukkan perbedaan dari kelompoknya. Menurut pengakuan orangtua, anaknya tidak berperan sesuai dengan gendernya. Ada pula anak yang pernah ingin merubah gendernya, namun ini harus dilakukan penggalian lebih dalam untuk memahami pernyataan anak tersebut dari perspektif anak (Tampubolon, 2018).

Namun tentu saja, wacana gender ini tak bisa kita beratkan hanya pada kasus perempuan saja. Seperti pada pernyataan identity gender question yang peneliti ajukan, ternyata kasus dimana laki-laki dipaksa untuk selalu kuat itu juga merupakan suatu masalah gender yang harus dibenahi. Karena setiap orang memiliki batas kekuatannya masing-masing, karena tidak selamanya laki-laki itu harus menjadi kaum superior. Dan juga terkadang seringkali kita memandang laki-laki yang bersolek adalah laki-laki yang tidak maskulin dan akhirnya menjadi bahan cibiran, padahal sudah dijelaskan bahwa itu hal-hal yang sah-sah saja selagi masih dalam batas wajar dalam melakukannya.

Terkadang secara tidak sadar pula kita seringkali melakukan melegitimasi ketidakadilan gender pada diri sendiri, contohnya seorang perempuan yang padahal ia mampu untuk mengangkat barang berat, menjadi enggan jika mengangkatnya jika ada laki-laki, karena beranggapan laki-laki lebih kuat dan perempuan itu lemah. Padahal itu adalah salah satu pengambilan sikap yang sama, hingga akhirnya terjadilah konstruksi sosial yang melegitimasi perempuan itu lemah dan laki-laki itu kuat.

\section{Referensi}

Afandi, A. (2019). Bentuk-Bentuk Perilaku Bias Gender. In LENTERA: Journal of Gendera Children Studies (Vol. 1). Retrieved from https://journal.unesa.ac.id/index.php/JOFC

Fakih, M. (1996). Analisis Gender dan Transformasi Sosial. Yogyakarta: Pustaka Pelajar.

Fibrianto, A. S. (2016). Kesetaraan Gender Dalam Lingkup Organisasi Mahasiswa Universitas Sebelas Maret Surakarta Tahun 2016. In Jurnal Analisa Sosiologi (Vol. 5). https://doi.org/10.20961/JAS.V5I1.18422

Hadianti, A. N. (2010). Pendidikan Gender Pada Anak Usia Dini. Jurnal Penelitian \& Artikel Pendidikan, 2(4), 18-25. Retrieved from journal.ummgl.ac.id/index.php/edukasi/article/view/599

Janah, N. (2017). Telaah Buku Argumentasi Kesetaraan Gender Perspektif Al-Qur'an Karya Nasaruddin Umar. Sawwa: Jurnal Studi Gender. https://doi.org/10.21580/sa.v12i2.1707 
Musfiqon. (2012). Pengembangan Media Dan Sumber Pembelajaran. Malang: Prestasi Pustakakarya.

Nadiyah, U. (2019). Kesetaraan Gender. Retrieved from kompasiana website: https://www.kompasiana.com/urfiyahnadiyahfillah/5e5d29d9097f365fab085c13/kesetaraangender

Perempuan, K. P. (2001). Pemantapan Kesepakatan Mekanisme Operasional Pengarusutamaan Gender Kesejahteraan dan Perlindungan Anak dalam Pembangunan Nasional dan Daerah: Bagian I dan II. Jakarta.

Putra, H. S. A. (2000). Ketika Orang Jawa Nyeni. Yogyakarta: Galang Press.

Putri, R. D. (2019). No Budaya Adil Gender pada Pendidikan Anak Usia Dini Melalui Bermain Peran. JUANG: Jurnal Wahana Konseling, 2(1).

RI, K. (2010). Riset Kesehatan Dasar. Badan Penelitian dan Pengembangan Kesehatan Kementrian Kesehatan RI 2010. Jakarta.

Rokhmansyah, A. (2016). Pengantar Gender dan Feminisme : Pemahaman Awal Kritik Sastra Feminisme. Yogyakarta: Penerbit Garudhawaca.

Santoso, H. (2015). Disini Matahariku Terbit. Jakarta: PT. Erlangga.

Santrock, J. w. (2007). Buku Perkembangan Anak (11th ed.). Jakarta: PT. Erlangga.

Sugiyono. (2010). Metode Penelitian Kuantitatif dan R\&D. Bandung: Alfabeta.

Tampubolon, G. N. (2018). Identitas dan Peran Gender pada Anak Usia 3-7 Tahun dalam Keluarga Komuter. Jurnal CARE (Children Advisory Research and Education). 